\title{
Influence of Vacuum Level and Overmilking on Udder Health and Teat Thickness Changes in Dairy Ewes
}

\author{
C. Peris, ${ }^{\star}$ J. R. Díaz,† S. Balasch,‡ M. C. Beltrán, ${ }^{\star}$ \\ M. P. Molina, ${ }^{*}$ and N. Fernández* \\ *Department of Animal Science \\ †Department of Statistics \\ Universitat Politècnica de València \\ 46071 València, Spain \\ Cami de Vera, 14 \\ łDivisión Producción Animal. E.P.S.O. \\ Universidad Miguel Hernández \\ Ctra Boniel km 3.2 3312 Orihuela-Alicante, Spain
}

\section{ABSTRACT}

The effects of vacuum level and overmilking on udder health were studied in ewes. Vacuum levels of 36 and $42 \mathrm{kPa}$ were assigned to two groups of 23 Manchega ewes in a crossover study design with two experimental periods of $5 \mathrm{wk}$ for each. Moreover, for each ewe, one teat was overmilked 1.5 to 2 min at all milkings during these $10 \mathrm{wk}$. The milking machine used had a midlevel milkline and pulsation was fixed at 180 cycles per min and a pulsation ratio of 50:50. Bacterial exposure of all teats was increased by dipping them in a suspension of Staphylococcus simulans at eight milkings of each period. New intramammary infections (IMI) were not significantly affected by the vacuum level used (18 and $23 \%$ of ewes infected, at 36 and $42 \mathrm{kPa}$, respectively) or application of overmilking (9 and $11 \%$ of half udders infected without and with overmilking, respectively). Likewise, neither factor significantly affected the somatic cell count (SCC) of the milk. Teat thickness changes after milking varied significantly due to the presence of overmilking ( -13.6 and $-7.4 \%$, in teats not overmilked and overmilked, respectively) but were not affected by vacuum level. At no time were any lesions or variations visibly noted in the teat walls or orifice. So, in this work we were unable to demonstrate that the vacuum and overmilking levels assayed, both used with a pulsation rate of 180 cycles/min, have an important effect on the state of udder health in the short term. Furthermore, it was also observed that, in absence of IMI, the two factors studied did not cause irritation of any kind in the gland that might influence the SCC of the milk.

Received January 29, 2003.

Accepted May 16, 2003.

Corresponding author: C. Peris; e-mail: cperis@dca.upv.es.
(Key words: vacuum level, overmilking, somatic cell count, teat thickness).

\section{INTRODUCTION}

Works carried out in cows have demonstrated that faulty design and/or use of milking machine can increase the rate of IMI and the SCC of tank milk, mainly due to two aspects. On one hand, milking in inadequate conditions can have a negative effect on teat condition (Hamann, 1987; Hamann et al., 1994a), which would negatively affect local defense mechanisms against infectious agents and, in consequence, increase the risk of germs colonizing the teat canal (Zecconi et al., 1992) and establishing IMI (Hamann et al., 1994a; Zecconi et al., 1996). On the other hand, the milking machine can also constitute a vector for transference of pathogens to the teat, either passively by teat contact with the contaminated liner (Woolford et al., 1980) or actively, if important fluctuations are generated in teat end vacuum (liner slips, teatcup falls off) that may give rise to reverse milk flows (Billón et al., 1998) and "impact" of bacteria-contaminated milk droplets against the teat (O'Shea, 1987). These impacts, and possibly also the phenomenon designated "reverse pressure gradient" across the teat canal (Galton et al., 1988; Rasmussen et al., 1994), could be responsible for the bacteria reaching or even passing through the canal during milking.

In mechanical milking, a relevant aspect that may influence the state of udder health is the vacuum level existing in the teat area. In cows, several works have reported that excessively high vacuum levels, generally over $50 \mathrm{kPa}$ at the milkline, can have a negative effect on teat condition (Langlois et al., 1980) and increase mastitis incidence (Galton and Mahle, 1980; Langlois et al., 1980; Osteras and Lund, 1988). In contrast, excessively low vacuum levels in relation to milking cluster weight will tend to increase liner slips and unit fall-off 
(Spencer and Rogers, 1991), which could involve greater risk of impacts and IMI (Baxter et al., 1992) as well as negatively affecting handling during milking, milk flow, and machine on time (Rasmussen and Madsen, 2000). In this sense, international standards for cows (ISO, 1996) recommend that during the maximum flow period the mean claw vacuum should be set between 32 and $40 \mathrm{kPa}$. There are no specific recommendations for dairy ewes (Billon et al., 2002), although in recent years in the field a tendency to reduce the working vacuum level of the milking machine installations has been observed, going from 42 to $44 \mathrm{kPa}$ to 34 to $36 \mathrm{kPa}$ (Billon et al., 1999). This has been possible because the weight of clusters has also tended to decrease. Nevertheless, very few works have studied the effect of these levels of vacuum on udder health in ewes.

Another aspect widely studied in cows is the relationship between overmilking and mastitis, although results obtained have not always coincided (O'Shea, 1987). Overmilking causes greater teat tissue congestion/edematiation (Hamann, 1990; Isaksson and Lind, 1992) and in field conditions has been associated with a worse teat end condition (Osteras et al., 1990; Huusko et al., 2002). Under experimental conditions it has not always been possible to relate overmilking to the presence of teat lesions or higher new infection rate (O'Shea, 1987; Hamann et al., 1994b). Moreover, the results of some works (Natzke et al., 1978, 1982; Mein et al., 1986) suggest that the effects of a moderate overmilking would be especially important when associated with other problems, such as pulsation failures (pulsator or liners) or vacuum fluctuations (Hamann et al., 1994b).

There is limited information on the influence of the cited machine factors on mammary gland health in dairy ewes. Our objective was to study the influence of two vacuum levels (36 vs $42 \mathrm{kPa}$ ) and the presence of overmilking (without overmilking vs. overmilking of 1.5 to $2 \mathrm{~min}$ ) on IMI rates, SCC, and teat thickness changes in dairy ewes.

\section{MATERIALS AND METHODS}

\section{Experimental Design}

This work was carried out on the experimental farm flock of the Animal Science Department of the Polytechnic University of Valencia. The animals were stabled throughout the lactation period and machine milked twice daily at 0800 and $1730 \mathrm{~h}$. For 3 wk after lambing, ewes were milked with a vacuum level of $36 \mathrm{kPa}$ (preexperimental period). Next, 46 ewes without IMI were selected from the flock and blocked into 23 pairs (8 first lactation and 15 older ewes) based on parity, milk production, and milking rate. Each pair was randomly divided and one ewe was assigned the vacuum level of
$42 \mathrm{kPa}$, while the other was assigned the $36 \mathrm{kPa}$, for a period of $35 \mathrm{~d}$ (first experimental period); in this period 1 ewe was affected by clinical mastitis and was removed from the experiment. Then, ewes were reversed between milking groups for another 35-d period (second experimental period). During all milkings in both experimental periods ( $70 \mathrm{~d}$ in total), one teat per udder, always the same, was identified and overmilked for 1.5 to $2 \mathrm{~min}$. The teats to be overmilked were chosen at random. With the aim of enhancing the level of exposure to pathogens at the teats in the experimental periods, two actions were performed. On the one hand, the two experimental groups were always milked after a group of 15 ewes with mastitis; in addition, the milking order of the two experimental groups was changed weekly and each day at the morning and afternoon milking. On the other, in the two milkings of $d 7,8,14$, and 15 (8 milkings in total) from initiation of each of the experimental periods, all teats were immersed in a suspension of Staphylococcus simulans $\left(5 \times 10^{7} \mathrm{cfu} / \mathrm{ml}\right)$ immediately before application of the milking unit.

\section{Equipment and Milking Method}

Ewes were milked in a milking parlor $(2 \times 12)$ with six cluster and a milk pipeline at $1.0 \mathrm{~m}$ above the platform (midlevel). Claw had a volume of $91 \mathrm{ml}$, with an air vent $(6 \mathrm{~L} / \mathrm{min})$ and a manual vacuum shut-off valve. Liner was made of silicone and had the following features: mouthpiece bore: $19 \mathrm{~mm}$; barrel bore: $17.5 \mathrm{~mm}$; length $99 \mathrm{~mm}$; rigidity (minimum vacuum necessary to close liner barrel within shell): $8 \mathrm{kPa}$. The weight of the milk cluster installed, that is the weight actually suspended from the udder, was $156 \mathrm{~g}$. Three electromagnetic pulsators driven by an electronic control box supplied pulsation to the clusters (two clusters per pulsator). Pulsation rate (180 $\mathrm{p} / \mathrm{min})$ and ratio (50:50), and real reserve $(780 \mathrm{~L} / \mathrm{min})$ were unchanged throughout the experiment. The milking machine and pulsation were monitored three times during the study, at the beginning of the preexperimental stage and each of the experimental periods. Vacuum level near the teat was measured at the short milk tube with an electronic device (Alphatronic IV, De Laval Agri, Tumba, Sweden). With a vacuum of $36 \mathrm{Kpa}$ at the regulator, average vacuum near the teat was $35.5 \mathrm{kPa}$ with no milk flow and of $32.5 \mathrm{kPa}$ with milk flow; with a vacuum of 42 $\mathrm{kPa}$ at the regulator, the respective vacuum averages recorded were 41 and $38.5 \mathrm{kPa}$. To be able to apply overmilking to one of the glands of each animal, clips were installed in the short milk tubes. When milk flow ceased (normally 60 to $70 \mathrm{~s}$ after attaching the teatcups) the vacuum was cut off with the clip and the teatcup withdrawn from the gland not overmilked. From 1.5 to 
2 min later (2.5 to 3 min after initially attaching the teatcups) the teatcup that had been removed was replaced on the teat, the clip was opened and machine stripping was applied as a vigorous udder massage for 5 to $8 \mathrm{~s}$ to both glands. During the two experimental periods, teats were not dipped in iodine.

\section{Bacterial Challenge}

The strain of $S$. simulans utilized came from a gland with subclinical mastitis from a commercial flock. The bacterial suspension $\left(5 \times 10^{7} \mathrm{fcu} / \mathrm{ml}\right)$ used to dip the teats was prepared according to Hogan et al. (1990) and methodology already described in a previous work (Peris et al., 2003).

\section{Data Acquisition}

Bacteriological analyses and SCC of all teats (half udder samples) were recorded at two morning milking days per week during the preexperimental and experimental periods ( 26 records per teat). In addition, SCC was analyzed at the whole milk obtained per ewe (udder samples) at the morning milking, with a frequency of once a week. Teat thickness and visual observation of teat condition of all teats were recorded six times: two in the preexperimental period and two during each experimental period. Teatcup fall-off was recorded one day a week, at the morning and afternoon milking; audible liner slips were accounted as teatcup fall-offs.

The methodology used to carry out the bacteriological analysis (sample collection, inoculum, incubation, and diagnostic procedures) and SCC may be consulted in Peris et al. (2003). Teat end edema created by the milking machine was estimated with a "cutimeter" (no. 33865; Hauptner, D-42651 Solingen), measuring the teat thickness change immediately after milking, according to Hamann et al. (1996). "Teat thickness" has been defined as the distance $(\mathrm{mm})$ between the springloaded caliper jaws for a given applied pressure. The difference in the measured teat thickness before and after milking largely reflects changes in the mass of tissue and fluid in the teat (Hamann and Mein, 1990). So, measurements for each teat were taken before $(\mathrm{m} 1)$ and after $(\mathrm{m} 2)$ milking, and post-milking teat thickness changes were calculated as $(\mathrm{m} 2-\mathrm{m} 1)$ and, as a percentage, $(\mathrm{m} 2-\mathrm{m} 1) \times 100 / \mathrm{m} 1$.

\section{Statistical Analysis}

Teat thickness changes data were analyzed statistically according to the following model:

$$
\mathrm{Y}_{\mathrm{ijklm}}=\mu+\mathrm{T}_{\mathrm{i}}+\mathrm{I}_{\mathrm{j}}+\mathrm{O}_{\mathrm{k}}+\mathrm{P}_{\mathrm{l}}+\mathrm{TO}_{\mathrm{ik}}+\mathrm{e}_{\mathrm{ijklm}}
$$

where

$$
\begin{aligned}
\mathrm{Y}_{\mathrm{ijklm}}= & \text { arithmetical mean of teat thickness changes } \\
& \text { at the first or second experimental period, } \\
\mu= & \text { mean, } \\
\mathrm{T}_{\mathrm{i}}= & \text { fixed effect of the vacuum level }(36 \text { or } 42 \mathrm{kPa}), \\
\mathrm{I}_{\mathrm{j}}= & \text { random effect of the ewe, } \\
\mathrm{O}_{\mathrm{k}}= & \text { fixed effect of overmilking (half udder with } \\
& \text { overmilking and half udder without over- } \\
& \text { milking), } \\
\mathrm{Pl}= & \text { fixed effect of the experimental period (first } \\
& \text { or second), } \\
\mathrm{TO}_{\mathrm{ik}}= & \text { vacuum level } \times \text { overmilking interaction, and } \\
\mathrm{e}_{\mathrm{ijkl}}= & \text { residual effect. }
\end{aligned}
$$

In the SCC data, there was a residual effect between the first and second experimental periods because the infected glands in the first period continued infected throughout the second period. Thus, SCC data were statistically analyzed separately for each experimental period. In the second experimental period, only ewes uninfected at the beginning of this period (36 ewes) were considered. In all cases, SCC data were $\log _{10^{-}}$ transformed (Ali and Shook, 1980) before analysis because the SCC were not normally distributed.

SCC data from halve udders (samples by teat) were analyzed with the following statistical model:

$$
\begin{gathered}
\mathrm{Y}_{\mathrm{ijklm}}=\mu+\mathrm{T}_{\mathrm{i}}+\mathrm{O}_{\mathrm{j}}+\mathrm{I}_{\mathrm{k}}(\mathrm{TiO} \mathrm{Oj})+\mathrm{D}_{\mathrm{l}}+\mathrm{TO}_{\mathrm{ij}} \\
+\mathrm{TD}_{\mathrm{il}}+\mathrm{OD}_{\mathrm{jl}}+\mathrm{e}_{\mathrm{ijklm}}
\end{gathered}
$$

where:

$$
\begin{aligned}
\mathrm{Y}_{\mathrm{ijk} k m}= & \text { SCC in log, } \\
\mu= & \text { mean, } \\
\mathrm{T}_{\mathrm{i}}= & \text { fixed effect of the vacuum level (36 or } 42 \\
& \mathrm{kPa}), \\
\mathrm{O}_{\mathrm{j}}= & \text { fixed effect of overmilking (half udder with } \\
& \text { overmilking and half udder without over- } \\
& \text { milking), } \\
\mathrm{I}_{\mathrm{k}}\left(\mathrm{Ti} \mathrm{O}_{\mathrm{j}}\right)= & \text { random effect of the half udder nested } \\
& \text { within vacuum level and overmilking } \\
& \text { groups, } \\
\mathrm{D}_{1}= & \text { fixed effect of the record day, } \\
\mathrm{TO}_{\mathrm{ij}}= & \text { vacuum level } \times \text { overmilking interaction, } \\
\mathrm{TD}_{\mathrm{il}}= & \text { vacuum level } \times \text { day interaction, } \\
\mathrm{OD}_{\mathrm{jl}}= & \text { overmilking } \times \text { day interaction, and } \\
\mathrm{e}_{\mathrm{ijk}}= & \text { residual effect. }
\end{aligned}
$$

Somatic cell count data from the whole milk udder were analyzed with the above statistical model [2], but without the effects of overmilking and its interactions, considering the $I_{k}$ effect as the random effect of the ewe. 
PERIS ET AL.

Table 1. New IMI according to the vacuum level used and application or not of overmilking in ewes.

\begin{tabular}{|c|c|c|c|c|c|c|c|}
\hline \multirow{3}{*}{$\begin{array}{l}\text { Experimental } \\
\text { period }^{1}\end{array}$} & \multirow{3}{*}{$\begin{array}{l}\text { Vacuum } \\
\text { level } \\
(\mathrm{kPa})\end{array}$} & \multicolumn{4}{|c|}{ New half-udders infected ${ }^{3}$} & & \\
\hline & & \multicolumn{2}{|c|}{ Overmilking $^{2}$} & \multicolumn{2}{|c|}{ No overmilking } & \multicolumn{2}{|c|}{ New ewes ${ }^{3}$ infected } \\
\hline & & High SCC $^{4}$ & Total & High SCC & Total & High SCC & Total \\
\hline \multirow[t]{2}{*}{ First } & 36 & $0 / 23$ & $1 / 23$ & $1 / 23$ & $2 / 23$ & $1 / 23$ & $3 / 23$ \\
\hline & 42 & $3 / 23$ & $4 / 23$ & $1 / 23$ & $4 / 23$ & $4 / 23$ & $7 / 23$ \\
\hline Second & $\begin{array}{l}36 \\
42\end{array}$ & $\begin{array}{l}1 / 19 \\
1 / 22\end{array}$ & $\begin{array}{l}3 / 19 \\
2 / 22\end{array}$ & $\begin{array}{l}1 / 18 \\
1 / 21\end{array}$ & $\begin{array}{l}1 / 18 \\
1 / 21\end{array}$ & $\begin{array}{l}2 / 16 \\
2 / 20\end{array}$ & $\begin{array}{l}4 / 16 \\
3 / 20\end{array}$ \\
\hline \multirow[t]{3}{*}{ Global } & $\begin{array}{l}36 \\
42\end{array}$ & $\begin{array}{l}1 / 42(2 \%) \\
4 / 45(9 \%)\end{array}$ & $\begin{array}{l}4 / 42(10 \%) \\
6 / 45(13 \%)\end{array}$ & $\begin{array}{l}2 / 41(5 \%) \\
2 / 44(5 \%)\end{array}$ & $\begin{array}{l}3 / 41 \quad(7 \%) \\
5 / 44(11 \%)\end{array}$ & $\begin{array}{l}3 / 39(8 \%) \\
6 / 43(14 \%)\end{array}$ & $\begin{aligned} 7 / 39 & (18 \%) \\
10 / 43 & (23 \%)\end{aligned}$ \\
\hline & $P$ & $0.19^{\mathrm{NS}}$ & $0.56^{\mathrm{NS}}$ & $0.94^{\mathrm{NS}}$ & $0.52^{\mathrm{NS}}$ & $0.36^{\mathrm{NS}}$ & $0.55^{\mathrm{NS}}$ \\
\hline & Overall & $5 / 87(6 \%)$ & $10 / 87(11 \%)$ & $4 / 85(5 \%)$ & $8 / 85(9 \%)$ & & \\
\hline
\end{tabular}

${ }^{1}$ In each 5 -wk experimental period all teats were challenged in eight milkings in a suspension of $S$. simulans $\left(5 \times 10^{7} \mathrm{cfu} / \mathrm{ml}\right)$.

${ }^{2}$ Only one teat per udder was overmilked during the two experimental periods (10 wk).

${ }^{3}$ No. new IMI/No. total healthy udder halves or ewes at the outset of each experimental period.

${ }^{4} \mathrm{IMI}$ that provoked a elevation of SCC higher than 500,000 cells $/ \mathrm{ml}$ in practically all the records.

With the aim of determining the effect of the vacuum level and overmilking on SCC of uninfected glands or udders, $\log _{10}$ SCC data from ewes that remained uninfected throughout the experiment ( 29 ewes) were analyzed statistically using the model [1] described previously. In the whole udder SCC data, in model [1] the effects of overmilking and its interactions were not considered.

All these statistical analyses were carried out with the mixed procedure from the SAS program (SAS, 1996).

Association of vacuum level and overmilking with the frequency of new IMI were assessed by chi-square analysis using the Freq procedure of SAS (SAS, 1996).

\section{RESULTS}

The number and proportion of new IMI in each of the two experimental periods are shown in Table 1; the IMI where an important increase in SCC may be observed (higher than 500,000 cells $/ \mathrm{ml}$ ) are also shown separately in this table. It must be noted that in the first experimental period a half udder (at $42 \mathrm{kPa}$ and overmilking) was affected by acute clinical mastitis (Staphylococcus aureus), and the ewe was withdrawn from the experiment. Vacuum level had no significant effect $(P$ $>0.1$ ) on the proportion of total new IMI, whether considering only the udder halves overmilked (10 and 13\% of IMI at vacuum level of 36 and $42 \mathrm{kPa}$, respectively) or the udder halves not overmilked ( 7 and $11 \%$ ) or at udder level (18 and 23\% of IMI; respectively). The same trend was observed when considering only those infections with high SCC (Table 1), as vacuum level did not significantly $(P>0.1)$ affect the new IMI of half udders (with overmilking: 2 and $9 \%$ of IMI at 36 and $42 \mathrm{kPa}$, respectively; without overmilking: 5 and 5\%, respectively), and of ewes (8 and 14\%). Besides, overmilking did not demonstrate a significant effect on the rate of new IMI (total IMI: 11 and 9\% in glands overmilked and not overmilked, respectively, $P=0.66$; IMI with high SCC: 6 and 5\%, respectively; $P=0.76$ ).

Table 2 includes the frequency of the different bacteria isolated, as well as their influence on SCC. Most of the infections, 9 of 18, were caused by the same bacteria used to carry out the immersions (S. simulans), whereas the other infections were caused by Staphylococcus epidermidis (three infections), S. aureus (clinical infection), CNS, Corynebacterium spp., and Streptococcus spp.-in these last three cases it was not possible to identify the species. Except in one case, the rest of the infections were persistent, remaining until the end of lactation.

Only in half (9 of 18) of the infected glands was an important increase in SCC observed (greater than 500,000 cells $/ \mathrm{ml}$ in practically all records). Likewise, it is possible that some of the glands considered as infected, but with low SCC, of less than 200,000 cells/ $\mathrm{ml}$, actually corresponded to teat canal colonizations. It must be emphasized that the SCC of the healthy glands were usually lower than 150,000 cells $/ \mathrm{ml}$.

In the analyses performed at glandular and udder level, and in the first and second experimental period, SCC was significantly affected by the day effect $(P<$ 0.001 ), although not by the effects of vacuum level, overmilking (Table 3 ) and interactions overmilking $\times$ vacuum and overmilking $\times$ day (Table 3 ). Interaction vacuum $\times$ day was only significant $(P<0.001)$ in the second experimental period, in the analyses performed both at glandular and udder level. However, this inter- 
Table 2. Number of ewe half udders infected and SCC geometrical mean in the different germ isolated at the experiment.

\begin{tabular}{|c|c|c|c|c|c|}
\hline \multirow[b]{3}{*}{ Germ } & \multicolumn{5}{|c|}{ No. of half udder infected } \\
\hline & \multirow{2}{*}{$\begin{array}{l}\text { No. Total } \\
\text { glands }\end{array}$} & \multicolumn{2}{|c|}{ With high $\mathrm{SCC}^{1}$} & \multicolumn{2}{|c|}{ With low $\mathrm{SCC}^{2}$} \\
\hline & & No. glands & $\mathrm{SCC}^{3}$ & No. glands & $\mathrm{SCC}^{3}$ \\
\hline S. simulans & 9 & 5 & 1730 & 4 & 62 \\
\hline S. epidermidis & 3 & 1 & 1599 & 2 & 49 \\
\hline S. aureus & 1 & 1 & 12,921 & 0 & \\
\hline CNS spp. ${ }^{4}$ & 1 & 0 & $\ldots$ & 1 & 44 \\
\hline S. xylosus & 1 & 1 & 1811 & 0 & \\
\hline Corynebacterium spp. & 2 & 0 & .. & 2 & 118 \\
\hline Streptococcus spp. & 1 & 1 & 2511 & 0 & $\ldots$ \\
\hline Total & 18 & 9 & 2768 & 9 & 63 \\
\hline
\end{tabular}

${ }^{1} \mathrm{SCC}$ higher than $500,000 \mathrm{cells} / \mathrm{ml}$ in practically all the samples.

${ }^{2} \mathrm{SCC}$ lower than 200,000 cells $/ \mathrm{ml}$ in practically all the samples.

${ }^{3} \mathrm{SCC}$ geometrical mean $\left(\times 10^{3} \mathrm{cell} \mathrm{s} / \mathrm{ml}\right)$.

${ }^{4}$ Coagulase negative staphylococci.

action did not represent a trend in SCC evolution in the 36 and $42 \mathrm{kPa}$ groups, given that the differences in SCC between these groups changed alternately throughout the record days (data not shown). On the other hand, when considering only the ewes that remained uninfected in either of the two experimental periods (29 ewes; Table 3), it was not found that SCC were affected significantly by the vacuum, overmilking and their interaction. This may also be seen in Figure 1 (vacuum level) and Figure 2 (overmilking), where the evolution of the arithmetical means of the SCC of glands from the ewes remaining free of IMI in both experimental periods is presented.

No alteration of teat canal orifice was observed visually, nor lesions in teat tissue provoked by the vacuum level or overmilking. However, teat thickness change after milking was significantly affected by overmilking $(P<0.001)$ and interaction vacuum $\times$ overmilking $(P<$ 0.05). Effectively, half udders overmilked suffered a significant increase in teat thickness change after milking (Table 4), differences being higher with the vacuum level of $42 \mathrm{kPa}$ (glands not overmilked: $-0.84 \mathrm{~mm}$; overmilked: $-0.38 \mathrm{~mm}, P<0.001)$ than with the vacuum of $36 \mathrm{kPa}$ (glands not overmilked: $-0.84 \mathrm{~mm}$; overmilked: $-0.59 \mathrm{~mm} ; P<0.01)$. On the contrary, vacuum affected teat thickness changes significantly $(P<0.05)$ only in the half udders overmilked, but not in the glands not overmilked. These same facts can be observed when considering teat thickness changes in percentage (Table 4).

Table 3. Effects of the vacuum level and overmilking on SCC considering a) udder halves/ewes infected and not infected in each experimental period or b) ewes that remained not infected throughout the experiment.

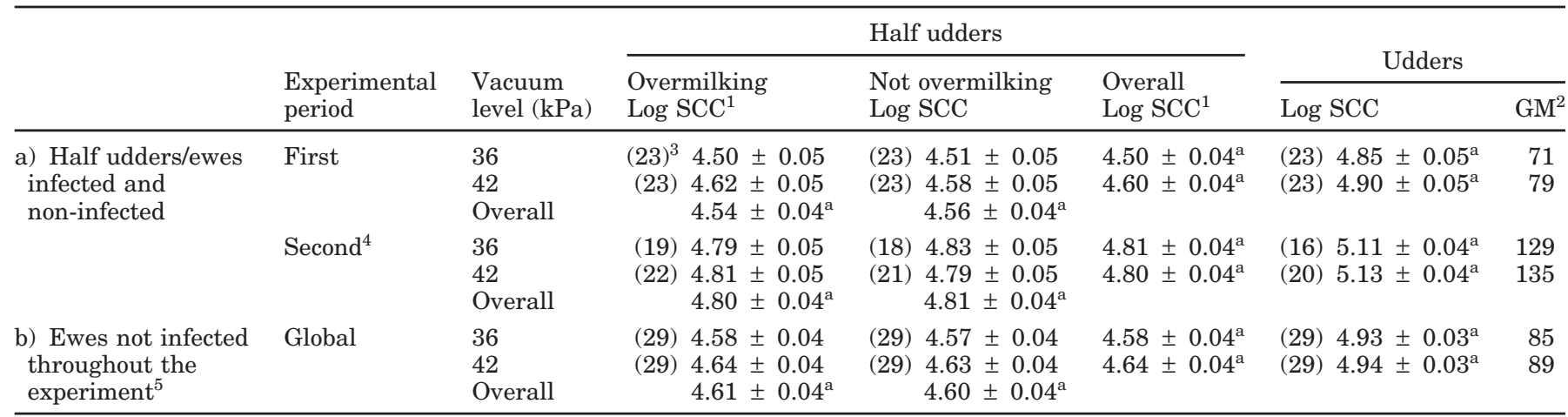

${ }^{a}$ Means in a row or column with the same superscript do not differ $(P>0.05)$.

${ }^{1} \mathrm{~m} \pm \mathrm{ES}$.

${ }^{2} \mathrm{GM}=$ geometrical mean $\left(\times 10^{3}\right.$ cells $\left./ \mathrm{ml}\right)$.

${ }^{3}(\mathrm{n})=$ number of cases.

${ }^{4}$ Only half udders/ewes not infected at the beginning of this experimental period were considered.

${ }^{5}$ Group A: 17 ewes; Group B: 12 ewes. 
a) Half udders not overmilked

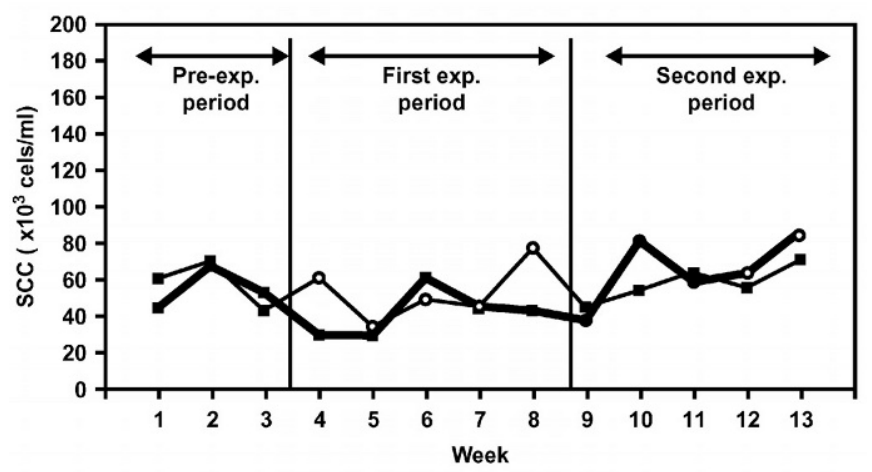

b) Half udders overmilked

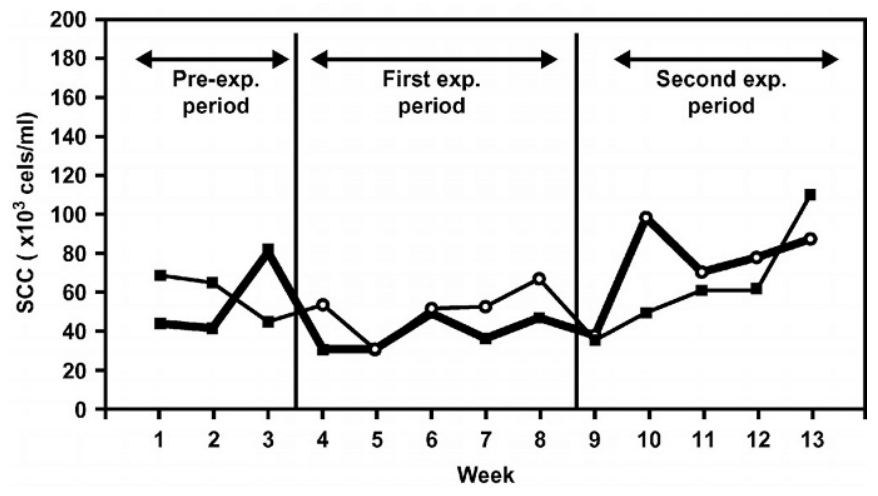

Figure 1. Evolution of the SCC arithmetical mean in half udders not overmilked (Fig. 1a) and overmilked (Fig. 1b) from two groups of ewes that remained uninfected throughout the experiment (Group $\mathrm{A}, \mathrm{n}=17, \longrightarrow$; Group B, $\mathrm{n}=12, \longrightarrow$ ) and were milked alternately with a vacuum level of $36(\square)$ or $42(\bigcirc) \mathrm{kPa}$. In the two experimental periods a half udder of each ewe was overmilked from 1.5 to 2 min. Pulsation rate $(180 \mathrm{p} / \mathrm{m})$ and ratio (50:50) were unchanged throughout the experiment. SCC was recorded two days in each week.

Teatcup fall-off was globally low (only 16 from 450 milkings recorded in the experimental periods) and did not differ significantly between the two vacuum levels assayed (1.6 and $1.9 \%$ at 36 and $42 \mathrm{kPa}$, respectively; $P>0.1$ ). Most (87\%) of the teatcup fall-offs were produced by the ewe kicking. Moreover, audible liner slips were very infrequent, recording only three cases (two at $36 \mathrm{kPa}$ and one at $42 \mathrm{kPa}$ ) in the experimental periods.

\section{DISCUSSION}

Many technicians currently consider that, at field level, a milking vacuum greater than $40 \mathrm{kPa}$ and the presence of overmilking are factors that tend to increase mastitis rates and SCC in tank milk in ewes. However, in this experiment, carried out with animals of a medium productive level $(1 \mathrm{~L} / \mathrm{d}$ of milk, on average $)$ and in conditions that may be considered suitable in terms

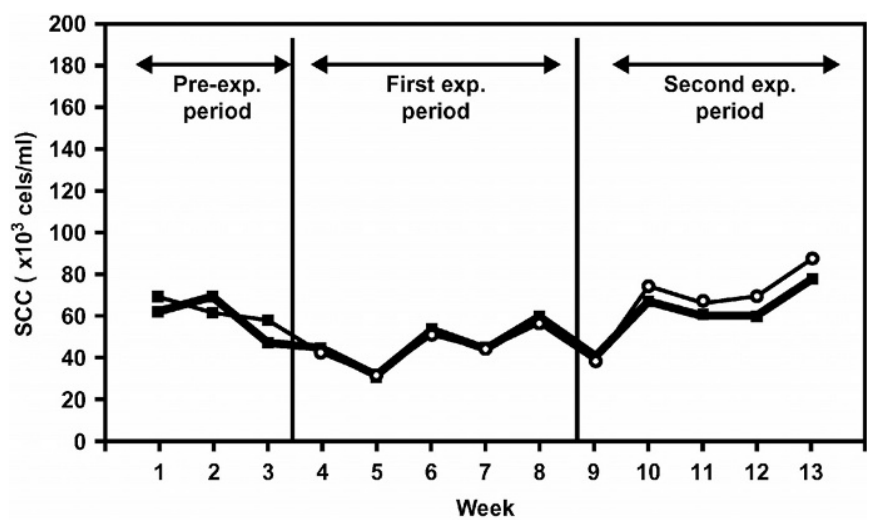

Figure 2. Evolution of the SCC arithmetical mean in half udders not overmilked $(\square)$ and overmilked $(\bigcirc)$ from 29 ewes (Group A, n = 17 , —— Group B, $\mathrm{n}=12,-$ ) that remained uninfected throughout the experiment. During the two experimental periods a half udder from each ewe, always the same, was overmilked for 1.5 to 2 min. Vacuum level was of $36 \mathrm{kPa}$ in the pre-experimental period and 36 or $42 \mathrm{kPa}$ in the two experimental periods. Pulsation rate $(180 \mathrm{p} / \mathrm{m})$ and ratio (50:50) were unchanged throughout the experiment. SCC was recorded $2 \mathrm{~d}$ in each week.

of the milking machine (reserve, pulsation, low teatcup fall-off) and handling of milking (shut-off the milking vacuum to the claw before the cluster removal, application of machine stripping with care taken to avoid air infiltration between teats and liners), there was no significant effect of the assayed vacuum levels and overmilking, in the short term, on IMI rates and milk SCC.

In the case of vacuum level, it must also be noted that during the first experimental period a favorable trend was observed at the low vacuum level ( 3 and 7 ewes infected at 36 and $42 \mathrm{kPa}$, respectively), although the differences were neither significant nor confirmed in the second experimental period. Some works on ewes have found that as vacuum level is decreased to values around $40 \mathrm{kPa}$ or lower, the SCC also tends to diminish (Le Du, 1983; Pazzona et al., 1993; Fernández et al., 1998), although this effect was not reported in other cases (Molina et al., 1999a). Moreover, we can report that at both assayed vacuum levels the teatcup fall-off rate was similar and, under normal milking conditions (not overmilking), teat thickness changes were not affected. The latter result coincides with that observed in ewes by Marnet et al. (1996), who found no differences in postmilking teat thickness changes when milking at 36 and $44 \mathrm{kPa}$, in both cases with a pulsation of $180 \mathrm{cycles} / \mathrm{min}$ and 50:50. In contrast, the information available in bovine indicates that in the interval from 25 to $50 \mathrm{kPa}$, as milking vacuum rises, teat thickness changes also increase, indicating a greater congestion/ edema of the teat (Hamann et al., 1993).

With regard to the effect of overmilking, it must first be emphasized that although it did have a significant 
Table 4. Effect of vacuum level and overmilking on postmilking teat thickness changes ( \pm ES), as a difference and a percentage of premilking values in ewes.

\begin{tabular}{lllll}
\hline & & \multicolumn{3}{c}{ Teat thickness change } \\
\cline { 2 - 5 } $\begin{array}{l}\text { Unit of } \\
\text { measure }\end{array}$ & $\begin{array}{l}\text { Vacuum } \\
\text { level } \\
(\mathrm{kPa})\end{array}$ & $\begin{array}{l}\text { Half udder } \\
\text { overmilked }\end{array}$ & $\begin{array}{l}\text { Half udder } \\
\text { not overmilked }\end{array}$ & Overall \\
\hline Difference & 36 & $(45)^{1}-0.59 \pm 0.07^{\mathrm{b}}$ & $(45)-0.84 \pm 0.07^{\mathrm{a}}$ & $-0.72 \pm 0.07$ \\
& 42 & $(45)-0.38 \pm 0.07^{\mathrm{c}}$ & $(45)-0.84 \pm 0.07^{\mathrm{a}}$ & $-0.62 \pm 0.07$ \\
& Overall & $-0.49 \pm 0.07$ & $-0.84 \pm 0.07$ & \\
Percentage & 36 & $(45)-8.9 \pm 1.1^{\mathrm{b}}$ & $(45)-13.5 \pm 1.1^{\mathrm{a}}$ & $-11.1 \pm 1.1$ \\
& 42 & $(45)-5.9 \pm 1.1^{\mathrm{c}}$ & $(45)-13.6 \pm 1.1^{\mathrm{a}}$ & $-9.8 \pm 1.1$ \\
& Overall & $-7.4 \pm 1.1$ & $-13.6 \pm 1.1$ & \\
\hline
\end{tabular}

${ }^{\mathrm{a}, \mathrm{b}, \mathrm{c}}$ Means in a row or column with different superscripts differ $(P<0.05)$.

${ }^{1}$ Value in parentheses indicates number of cases.

effect on the teat thickness changes, after $10 \mathrm{wk}$ of overmilking no repercussions were found on the presence of visible alterations or lesions in the teat walls and orifice, nor on IMI or SCC. Teat thickness changes values were clearly negative ( -6 to $-13 \%)$, that is, teat thickness after milking was narrower than before milking, which coincides with that cited in a previous work (Peris et al., 2003). The effect of overmilking was an increase in teat thickness after milking, although without reaching premilking values, and led to teat thickness changes values of zero, although these were clearly negative ( -6 to $-9 \%)$. In cows, Hamann and Mein (1996) recommend that teat thickness changes after milking should be lower than $+5 \%$, in order to prevent excessive teat congestion/edema, and greater than $-5 \%$, in order to limit an excessive compression load of the liner over the teat. However, according to our results, if this recommendation were to be applied in ewes, the teats would need to be milked at high vacuum levels (higher than $42 \mathrm{kPa}$ ) and/or with a systematic application of overmilking, which does not seem reasonable. Therefore, in our opinion the cited recommendation should not be directly applied to ewes, which leaves this issue open for study in future works.

On the other hand, the results of the present study, which was carried out under experimental conditions, would indicate that in the short term a moderate overmilking (in our case: 1.5 to $2 \mathrm{~min}$, that is, 1.5 to 2 times the normal milking duration) does not in itself seem to have any important effect on IMI rate or RCS. This idea coincides with that expressed by Hamann et al. (1994b) in cows or that encountered by Molina et al. (1999b) in dairy ewes. Nevertheless, bearing in mind the results and opinions of other authors studying cows (Bramley, 1992; O'Shea, 1987; Hamann et al., 1994b), it would seem prudent not to extrapolate the aforementioned conclusion a priori to any field level situation. Thus, the doubt remains concerning the effect that overmilking may have under one or several of the following conditions: greater overmilking time, effect over a longer term, simultaneous presence of other defects in milking (milk machine or routine) that could accentuate the overmilking effect on teat status or the presence of impacts.

Finally, the fact must also be noted that the vacuum levels and overmilking assayed did not cause any stress or irritation that would lead to an increase in SCC in the absence of IMI. In addition, our research group recently reported that pulsation rates (120 vs. $180 \mathrm{cy}-$ cles per minute) did not affect SCC in absence of mastitis infections either (Peris et al., 2003). Works carried out previously in bovines have also shown that overmilking (5 min), vacuum level (35 to $70 \mathrm{kPa}$ ), and pulsation rate (30 to 120 cycles/min) did not affect SCC in those animals without IMI (Olney and Scott, 1983; Olney and Mitchell, 1983). Therefore, it may be concluded that ewes and cows coincide in that the customary machine milking conditions will increase the SCC in milk if they influence the incidence or severity of the IMI, but will not affect the SCC of those animals free from IMI.

\section{CONCLUSIONS}

This work, carried out under experimental farm conditions, did not manage to demonstrate that, in the short term, the assayed levels of vacuum ( $36 \mathrm{vs} .42 \mathrm{kPa}$ ) and overmilking (1.5 to $2 \mathrm{~min}$ ) exert an important effect on the incidence of new IMI and SCC in ewes. Although neither factor provoked visible lesions in teat walls and orifice, overmilking did clearly increase teat thickness changes. Furthermore, in the absence of IMI, the two factors studied did not affect the SCC of the milk.

\section{ACKNOWLEDGMENTS}

The study was supported by project FAIR CT95-0881 of the European Commission (Brussels, Belgium). 


\section{REFERENCES}

Ali, A. K., and G. E. Shook. 1980. An optimum transformation for somatic cell concentration in milk. J. Dairy Sci. 63:487-490.

Baxter, J. D., G. W. Rogers, S. B. Spencer, and R. J. Eberhart. 1992. The effect of milking machine liner slip on new intramammary infections. J. Dairy Sci. 75:1015-1018.

Billon, P., O. Sauvee, J. L. Menard, and V. Gaudin. 1998. Effects of milking and of the milking machine on somatic cells counts and intramammary infections on dairy cows. Pages 305-312 in Proc. 5th Renc. Rech. Ruminants. INRA-Institut de L'Elevage, Paris France.

Billon, P., O. Ronningen, E. Sangiorgi, and E. Schuiling. 1999. Quantitative requirements of milking installations for small ruminants: A survey in different countries: milking and milk production of dairy sheep and goats. Pages 209-215 Proc. 6th Int. Symp. Milking Small Ruminants. EAAP Publication no. 95, Athens, Greece.

Billon, P., N. Fernández, O. Ronningen, F. Sangiorgi, and E. Schuiling. 2002. Quantitative recommendations for milking machines installations for small ruminants. Pages 4-21 in IDF Bull. no. 370.

Bramley, A. J. 1992. Mastitis and machine milking. Pages 343-372 in Machine Milking and Lactation. A. J. Bramley, F. H. Dodd, G. A. Mein, and J. A. Bramley, eds. Insight Books, Berkshire, England.

Fernández, N., J. R. Díaz, C. Peris, M. Rodríguez, M. P. Molina, and A. Torres. 1998. Machine milking parameters for the Manchega sheep breed. Pages 227-232 in 6th Int. Symp. Milking Small Ruminants. EAAP Publication No. 95. Athens, Greece.

Galton, D. M., and D. E. Mahle. 1980. Effects of vacuum level and pulsation ratio on udder health. Proc. Annu. Mtg. Nat. Mastitis Council Inc. 19:39-43.

Galton, D. M., D. J. Aneshansley, L. G. Peterson, C. S. Czarniecki, and N. R. Scott. 1988. Pressure gradients across the teat canal during machine milking. Page 114 in Proc. Milking Systems and Milking Manage. Symp. NE Reg. Agric. Eng. Serv., Ithaca, NY.

Hamann, J. 1987. Effect of machine milking on teat end condition. A literature review. Machine milking and new infection risk. Pages 5-28 in IDF Bull. no. 215.

Hamann, J. 1990. Machine-induced teat tissue reactions with emphasis on beta-adrenoceptor stimulation. Milchwissenschaft 45:782-786.

Hamann, J., and G. A. Mein. 1990. Measurement of machine-induced changes in thickness of the bovine teat. J. Dairy Res. 57:495-505.

Hamann, J., G. A. Mein, and S. Wetzel. 1993. Teat tissue reactions to milking: effects of vacuum level. J. Dairy Sci. 76:1040-1046.

Hamann, J., C. Burvenich, M. Mayntz, O. Osteras, and W. Haider. 1994a. Machine-induced changes in the status of the bovine teat with respect to the new infection risk. Pages 13-21 in IDF Bull. no. 297.

Hamann, J., O. Osteras, M. Mayntz, and W. Woyke. 1994b. Functional parameters of milking units with regard to teat tissue treatment. Pages 23-32 in IDF Bull. no. 297.

Hamann, J., and G. A. Mein. 1996. Teat thickness changes may provide biological test for effective pulsation. J. Dairy Res. 63:179-189.

Hamann, J., G. A. Mein, and N. Burkhard. 1996. Recommended method for measuring changes in thickness of the bovine teat with spring-loaded calipers. J. Dairy Res. 66:309-313.

Hogan, J. S., D. M. Galton, R. J. Harmon, S. C. Nickerson, S. P. Oliver, and J. W. Pankey. 1990. Protocols for evaluating efficacy of postmilking teat dips. J. Dairy Sci 73:2580-2585.

Huusko, M., M. Yli-Hynnila, K. Dredge, and S. Pyorala. 2002. Teatend condition and udder health of dairy cows in a health management project of dairy farms in South Pohjanmaa, Finland 1988. Suomen-Elainlaakarilehti 108:12-17.

Isaksson, A., and O. Lind. 1992. Teat reactions in cows associated with machine milking. J. Vet. Med. A 39:282-288.
International Organization for Standardization 1996. Milking machine installation. Construction and performance. ISO Standard no. 5707.

Langlois, B. E., J. C. Cox, R. W. Hemken, and J. Nicolai. 1980. Effect of milking vacuum on some indicators of bovine mastitis. J. Dairy Sci. 63(Suppl. 1):116-117.

Le Du, J. 1983. Effect of milk pipeline height on the milking characteristics of ewes. III International Symposium on the Milking of Small Ruminants. Pages 315-325 in 3rd International Symposium on the Milking of Small Ruminants Ed. Sever-Cuesta, Valladolid, Spain.

Marnet, P. G., J. F. Combaud, J. Le Du, and Y. Dano. 1996. Effect of pulsation rate and vacuum level on oxytocin release, milk parameters and teat end reaction. Page 114 in Proc. Symp. Milk Synthesis Secretion Removal Ruminants, Berne, Switzerland.

Mein, G. A. 1986. Effects on mastitis of overmilking in conjunction with pulsation failure. J. Dairy Res. 53:17-22.

Molina, A., C. Fernández, H. Vergara, and L. Gallego. 1999a. Effect of conditions and milking parameters on production, fractioning and composition of milk, and health status of udders in manchega ewes. Arch. Zootec. 48:135-146.

Molina, A., C. Fernández, H. Vergara, and L. Gallego. 1999b. Effect of milking condition and time on production and health status of udders in manchega ewes. Arch. Zootec. 48:147-156.

Natzke, R. P., P. A. Oltenacu, and G. H. Schmidt. 1978. Change in udder health with overmilking. J. Dairy Sci. 61:233-238.

Natzke, R. P., R. W. Everett, and D. R. Bray. 1982. Effect of overmilking on udder health. J. Dairy Sci. 65:117-125.

Olney, G. R., and R. K. Mitchell. 1983. Effect of milking machine factors on the somatic cell count of milk from cows free of intramammary infection. II. Vacuum level and overmilking. J. Dairy Res. 50:141-148.

Olney, G. R., and G. W. Scott. 1983. Effect of milking machine factors on the somatic cell count of milk from cows free of intramammary infection. III. Pulsator rate. J. Dairy Res. 50:149-152.

O'Shea, J. 1987. Machine milking factors affecting mastitis. A literature rewiew. IDF Bull 215:5-28.

Osteras, O., and A. Lund. 1988. Epidemiological analyses of the associations between bovine udder health and milking machine and milking management. Prev. Vet. Med. 6:91-108.

Osteras, O., I. Vagsholm, and A. Lund. 1990. Teat lesions with reference to housing and milking management. J. Vet. Med. A 37:520-524.

Peris, C., J. R. Díaz, C. Segura, A. Martí, and N. Fernández. 2003. Influence of Pulsation Rate on Udder Health and teat thickness changes in Dairy ewes. J. Dairy Sci. 86:530-537.

Pazzona, A., L. Murgia, and M. Sabelli. 1993. [Effect of milking vacuum and pulsation frequencies on leukocyte count in ewe milk]. Informatore Agrario (Italy) 42:43-46.

Rasmussen, M. D., E. S. Frimer, and E. L. Decker. 1994. Reverse pressure gradients across the teat canal related to machine milking. J. Dairy Sci. 77:984-993.

Rasmussen, M. D., and N. P. Madsen. 2000. Effects of milkline vacuum, pulsator airline vacuum, and cluster weight on milk yield, teat condition, and udder health. J. Dairy Sci. 83:77-84.

SAS/STAT Changes and Enhacements through Release 6.11. 1996. SAS Institute Inc., Cary, NC.

Spencer, S. B., and G. W. Rogers. 1991. Effect of vacuum and milking machine liners on liner slip. J. Dairy Sci. 74:429-432.

Woolford, M. W., J. H. Williamson, and D. S. M. Phillips. 1980. Aspects of milking machine design related to intramammary infection. Page 45 in Proc. Int. Workshop Machine Milking Mastitis. Moorepark, County Cork, Ireland.

Zecconi, A., J. Hamann, V. Bronzo, and G. Ruffo. 1992. Machineinduced teat tissue reactions and infection risk in a dairy herd free from contagious mastitis pathogens. J. Dairy Res. 59:265-271.

Zecconi, A., V. Bronzo, R. Piccinini, P. Moroni, and G. Ruffo. 1996. Field study on the relationship between teat thickness changes and intramammary infections. J. Dairy Res. 63:361-368. 